Gut, 1975, 16, 261-267

\title{
Ileal function in patients with untreated adult coeliac disease
}

\author{
D. B. A. SIlK, PARVEen J. KUMAR, JOAN P. W. WEBb, ANNETTE E. LANE, \\ M. L. CLARK, AND A. M. DAWSON
}

From the Departments of Gastroenterology and Medicine, St Bartholomew's Hospital and St Leonard's Hospital, London

SUMMARY A double-lumen perfusion technique has been used to investigate jejunal and ileal absorption of glucose, water, and electrolytes in a group of patients with untreated adult coeliac disease. Correct positioning of the tube was confirmed by measuring the differential jejunal and ileal handling of bicarbonate. Eight control subjects and eight patients with coeliac disease were perfused with an isotonic electrolyte solution containing $50 \mathrm{mM}$ glucose and $25 \mathrm{mM}$ bicarbonate.

The group of coeliac patients had impaired jejunal absorption of glucose $(\mathrm{P}<0.001)$, water $(P<0.01)$, sodium $(P<0.02)$, and chloride $(P<0.05)$ compared with the control group. In contrast the group of coeliac patients had normal ileal glucose and water absorption and increased ileal sodium $(P<0.01)$ and chloride $(P<0.05)$ absorption compared with the controls. Evidence for ileal adaptation was found in three individual patients.who had absorptive values outside2SD of the normal mean.

The results indicate that the distal small intestine in coeliac disease has the ability to adapt to the damage and loss of absorptive capacity in the proximal small intestine.

After jejunal resection and experimental jejunal bypass in the rat the remaining ileal mucosa becomes hypertrophied (Loran and Althausen, 1958; Booth, Evans, Menzies, and Street, 1959; Tilson and Wright, 1970; Weser and Hernandez, 1971; Bury, 1972; Gleeson, Dowling, and Peters, 1972). Studies of ileal function following jejunal resection or bypass showed enhanced absorption of glucose, water, and electrolytes (Dowling and Booth, 1967; Bury, 1972; Perry, 1973), maltose (Bury, 1972), bile salts(Perry, 1973), and vitamin $B_{12}$ (MacKinnon, 1972). Untreated adult coeliac disease might be compared to this experimental animal model because the mucosal lesion is more marked in the jejunum than in the ileum (Stewart, Pollock, Hoffbrand, Mollin, and Booth, 1967) and some patients absorb vitamin $B_{12}$ to a greater extent than normal subjects (Elias, MacKinnon, Short, and Dowling, 1973). Recent perfusion studies indicate that many patients with coeliac disease secrete fluid and electrolytes into the lumen of the upper jejunum (Fordtran, Rector, Locklear, and Ewton, 1967; Schmid, Phillips, and Summerskill, 1969; Russell, Allan, Gerskowitch,

Received for publication 16 January 1975. and Robertson, 1972; Silk, Kumar, Perrett, Clark, and Dawson, 1974a; Kumar, Silk, Rousseau, Pagaltsos, Clark, Dawson, and Marks, 1974). Despite these findings not all of these patients complained of either severe symptoms or diarrhoea (Silk $e t$ al, 1974a; Kumar et al, 1974). One explanation for this may be that ileal function is enhanced in patients with coeliac disease.

The present study was undertaken to explore this possibility; ileal function has been assessed in eight patients with untreated adult coeliac disease by studying absorption during ileal perfusion of an isoosmotic electrolyte solution containing $50 \mathrm{mM}$ glucose and $25 \mathrm{mM}$ bicarbonate. A direct comparison between ileal and jejunal function has been made by perfusing the same test solution through the jejunum of each subject studied. An ileal biopsy was obtained from each patient but owing to technical difficulties it was not always possible to correlate ileal morphology directly with function as a number of the perfusion experiments were carried out distal to the biopsy site. One of the problems that occurs when carrying out ileal perfusions is that one cannot always be sure that the test segment is correctly positioned. Initial studies 
carried out in normal subjects (Silk, Webb, Lane, Clark, and Dawson, 1974b) indicated that correct ileal positioning of the perfusion tube could be confirmed by using as a functional marker the differential handling of bicarbonate by the jejunum and ileum (Phillips and Summerskill, 1967), because, compared with in the jejunum, no significant absorption or even net secretion occurred in the ileum. The same criteria were used to confirm correct positioning of the perfusion tube during the ileal studies in coeliac patients.

\section{Materials and Methods}

\section{SUBJECTS}

Eight patients with untreated adult coeliac disease with a mean age of 38 years (range 18-57 years) were studied. The diagnosis of coeliac disease was established by history, physical examination, the usual laboratory criteria of malabsorption, and the typical histological appearance of the jejunal biopsy. All these patients subsequently showed clinical and morphological improvement when gluten was withdrawn from the diet. Relevant clinical details of the patients studied are shown in table I. We have no explanation for the low incidence of biochemical steatorrhoea in this group of random coeliac patients. It is of note, however, that the diagnosis was suspected mainly on haematological grounds in four cases.

Eight normal adult volunteers without evidence of gastrointestinal disease with a mean age of $\mathbf{4 0}$ years (range 22-47 years) acted as controls. The full purpose and nature of the study was.explained to all subjects and informed consent to the study was given in each case.

\section{BIOPSY TECHNIQUE}

Intestinal mucosal biopsies were obtained from the patients with untreated adult coeliac disease using the biopsy capsule of Crosby and Kugler (1957). Jejunal biopsies were taken under fluoroscopic control from a $10-\mathrm{cm}$ segment of upper jejunum beyond the duodenal-jejunal flexure and ileal biopsies were taken when the biopsy capsule was situated $140-200 \mathrm{~cm}$ from the mouth of each subject.

The biopsies were graded as normal, partial villous atrophy (PVA), or subtotal villous atrophy (SVA). Values in the coeliac patients were compared with the normal control data of Stewart et al (1967).

\section{Morphological Procedure}

Each biopsy was orientated on a ground glass slide and fixed in a $10 \%$ formaldehyde saline solution. They were then examined under a dissecting microscope and photographed. The histology was classified according to the criteria of Stewart et al (1967) with particular reference to villous height, mucosal thickness, and epithelial surface.

\section{EXPERIMENTAL TECHNIQUES}

The patients and normal control subjects were intubated with a double-lumen perfusion tube incorporating a proximal occlusive balloon as previously described (Silk et al, 1974b). The tube was allowed to pass until the infusion orifice was distal to the duodenal-jejunal flexure and the final

\begin{tabular}{|c|c|c|c|c|c|}
\hline \multirow[t]{2}{*}{ Patient } & \multirow{2}{*}{$\begin{array}{l}\text { Age }(y r) \text { and } \\
\text { Sex }\end{array}$} & \multicolumn{4}{|l|}{ Status at Diagnosis } \\
\hline & & Diarrhoea & $\begin{array}{l}\text { Faecal Fat } \\
(\mathrm{g} / 24 \text { hours })\end{array}$ & $\begin{array}{l}\text { Radiograph of } \\
\text { Small Intestine }\end{array}$ & Jejunal Biopsy \\
\hline F.A. & $25 \mathrm{~F}$ & $\begin{array}{l}\text { Severe } \\
\text { Bowels open } 10-15 / \text { day }\end{array}$ & $3 \cdot 2$ & $\begin{array}{l}\text { Thickened mucosal folds } \\
\text { with flocculation }\end{array}$ & SVA \\
\hline R.B. & $46 \mathrm{M}$ & Occasionally only & $1 \cdot 0$ & - & SVA \\
\hline P.F. & $43 \mathrm{M}$ & $\begin{array}{l}\text { Watery } \\
\text { Bowels open 2-3/day }\end{array}$ & - & Normal & SVA \\
\hline М.H. & $30 \mathrm{~F}$ & $\begin{array}{l}\text { Severe } \\
\text { Bowels open 4-5/day }\end{array}$ & $4 \cdot 7$ & Thickened mucosal folds & SVA \\
\hline E.K. & $57 \mathrm{~F}$ & $\begin{array}{l}\text { Diarrhoea in past, } \\
\text { constipated at time of } \\
\text { diagnosis }\end{array}$ & - & Dilatation & SVA \\
\hline J.Mc.M. & $54 \mathrm{~F}$ & $\begin{array}{l}\text { Mild, Bowels open } \\
\text { 2-3/day }\end{array}$ & $16 \cdot 7$ & $\begin{array}{l}\text { Carcinoma of ampulla } \\
\text { of Vater, small bowel } \\
\text { normal }\end{array}$ & SVA \\
\hline E.S. & $18 \mathrm{~F}$ & None & $2 \cdot 1$ & Normal & SVA \\
\hline C.F. & $28 \mathrm{~F}$ & $\begin{array}{l}\text { Intermittent diarrhoea, } \\
\text { Bowels open 4-6/day }\end{array}$ & $4 \cdot 7$ & $\begin{array}{l}\text { Dilated jejunum with } \\
\text { thickened mucosal folds, } \\
\text { clumping of barium }\end{array}$ & SVA \\
\hline
\end{tabular}

Table I Clinical details of patients with untreated adult coeliac disease 
position checked radiologically so that the $15 \mathrm{~cm}$ perfusion segment was positioned in the upper jejunum. The test solution was infused at $20 \mathrm{ml} / \mathrm{min}$ and after a 30-min equilibration period three 10-min samples were collected from the distal collecting orifice by simple syphonage. After the jejunal perfusion experiments had been completed each subject was permitted oral fluids and a light diet until midnight. During this period the perfusion tube was allowed to pass distally through the small intestine. The ileal perfusion experiments were carried out the following morning at which time the mercury bag was situated $180-210 \mathrm{~cm}$ from the mouth of each subject. The final position of the tube was checked radiologically to confirm that the infusion orifice appeared to lie in the distal small intestine.

\section{PERFUSION SOLUTION}

The jejunum and ileum of each subject was perfused with an isotonic electrolyte solution containing $50 \mathrm{mM}$ glucose, $25 \mathrm{mM}$ bicarbonate, $117 \mathrm{mM}$ sodium, $5 \mathrm{mM}$ potassium, and $96 \mathrm{mM}$ chloride. The solution contained a non-absorbable marker, polyethylene glycol (PEG), labelled with $1 \mu \mathrm{Ci}$ $\left({ }^{14} \mathrm{C}\right)$ PEG/1 (Wingate, Sandberg, and Phillips, 1972; Silk, 1974).

\section{LABORATORY MEASUREMENTS}

The glucose and bicarbonate contents of the perfusion solution and intestinal aspirates were analysed in a routine laboratory by standard methods. The glucose content was measured using a Technicon analyser (AA2) by a modification of the neocuproine method of Brown (1961). The bicarbonate content was measured using a Technicon 6/60 analyser (Skeggs and Hochstrasser, 1964). The $\left({ }^{14} \mathrm{C}\right)$ PEG content of the perfusion solutions and aspiration samples were measured as previously described (Silk, Perrett, Webb, and Clark, 1974c).
Calculations and statistics

Absorption rates were calculated from previously described formulae (Holdsworth and Dawson, 1964). The statistical significance of differences in absorption rates between the two groups of subjects was evaluated by the unpaired $t$ test (Langley, 1968).

\section{Results}

JEJUNAL MORPHOLOGY

All patients with untreated adult coeliac disease had subtotal villous atrophy of the jejunal mucosa. The villous height and surface cell heights were markedly reduced and mucosal thickness markedly increased compared with normal subjects (table II).

\section{JEJUNAL FUNCTION}

\section{Bicarbonate absorption}

The rates of bicarbonate absorption are shown in figure 1a. Although there was no significant difference between the rates of bicarbonate absorption by the group of normal subjects $(4 \cdot 2 \pm 2 \cdot 9)$ compared with the group of patients with coeliac disease $(1 \cdot 7 \pm 6 \cdot 0)$, three of the coeliac patients exhibited net secretion into the lumen of the jejunum. Values are the mean absorption rates expressed as m-equiv $\mathrm{hr}^{-1} 15 \mathrm{~cm}^{-1} \pm 2 \mathrm{SD}$.

\section{Glucose absorption}

The rates of glucose absorption are shown in figure 2a. There was severe impairment of glucose absorption by the group of coeliac patients $(6 \cdot 6 \pm$ 12.4) compared with the normal controls $(27 \cdot 3 \pm$ $13.7 ; \mathrm{P}<0.001)$. Values are the mean absorption rates expressed as $\mathrm{m} \mathrm{mol} \mathrm{hr} \mathrm{h}^{-1} 15 \mathrm{~cm}^{-1} \pm 2 \mathrm{SD}$. Each individual patient with coeliac disease had a glucose absorption value below 2SD of the normal mean.

\section{Water and electrolyte absorption}

The rates of water absorption are shown in fig $3 \mathrm{a}$

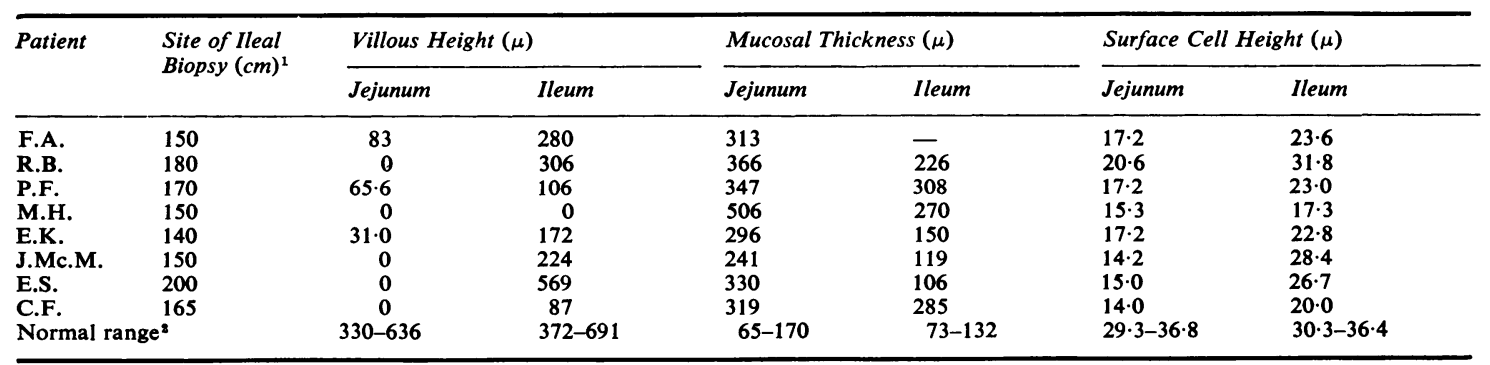

Table II Microscopic appearances of small intestinal mucosa

${ }^{1} \mathrm{Cm}$ from mouth of each subject.

${ }^{2}$ Normal data taken from Stewart et al (1967); $\mathbf{n}=10$. 


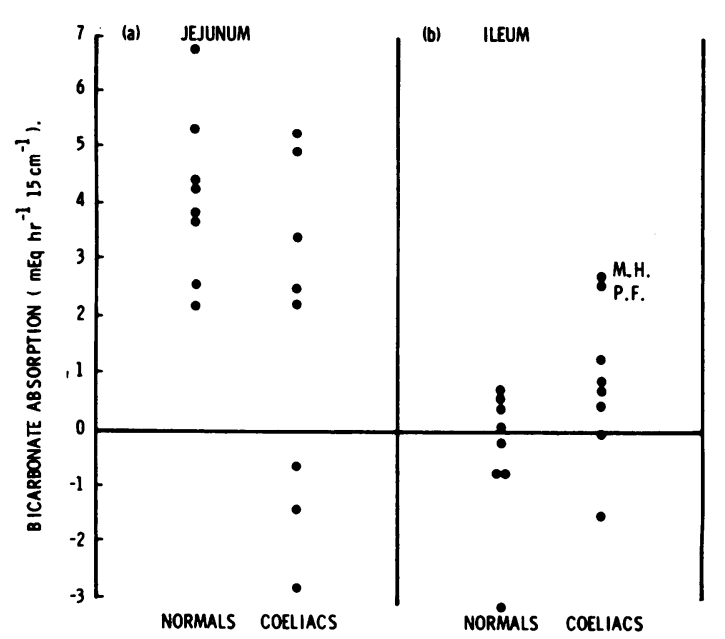

Fig 1 Absorption of bicarbonate from the jejunum (a) and the ileum (b). Negative sign indicates net secretion into the lumen of the intestine.

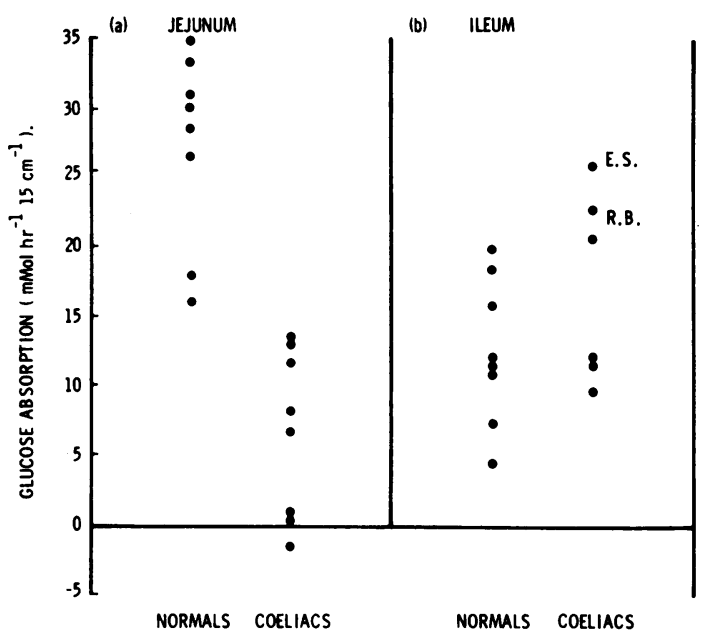

Fig 2 Glucose absorption from the jejunum (a) and from the ileum (b). Negative sign indicates net secretion into the lumen of the intestine.

and the rates of sodium and chloride absorption are shown in fig $4 \mathrm{a}$ and fig $5 \mathrm{a}$ respectively. There was severe impairment of water absorption by the group of coeliac patients $(-2 \cdot 3 \pm 254 \cdot 8)$ compared with the group of normal controls (183.7 \pm 140.5 ; $\mathbf{P}<0.01)$. The values are the mean absorption rates expressed as $\mathrm{ml} \mathrm{hr}^{-1} 15 \mathrm{~cm}^{-1} \pm 2 \mathrm{SD}$. Five patients exhibited net water secretion (values below 2SD of the normal mean). There was impairment of sodium absorption by the group of coeliac patients $(-2 \cdot 7 \pm 32 \cdot 0)$ compared with the group of normal controls $(15.2 \pm 19.0 ; \mathrm{p}<0.02$; fig $4 \mathrm{a})$. The values are the mean absorption rates expressed as $\mathrm{m}$ equiv $\mathrm{hr}^{-1} 15 \mathrm{~cm}^{-1} \pm 2 \mathrm{SD}$. The three patients who secreted bicarbonate into the lumen of the jejunum also exhibited net secretion of sodium into the lumen of the jejunum (values below 2SD of the normal mean). There was also impairment of chloride

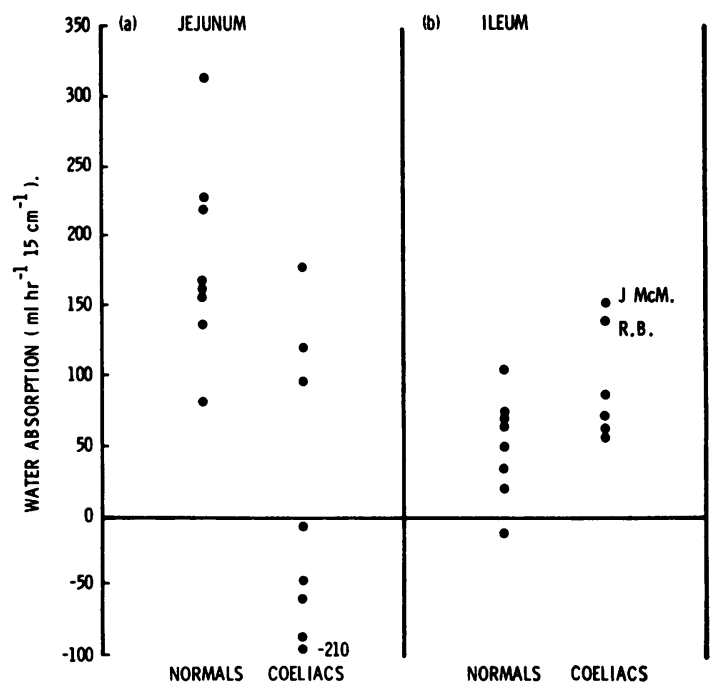

Fig 3 Water absorption from the jejunum (a) and from the ileum (b). Negative sign indicates net secretion into the lumen of the intestine.

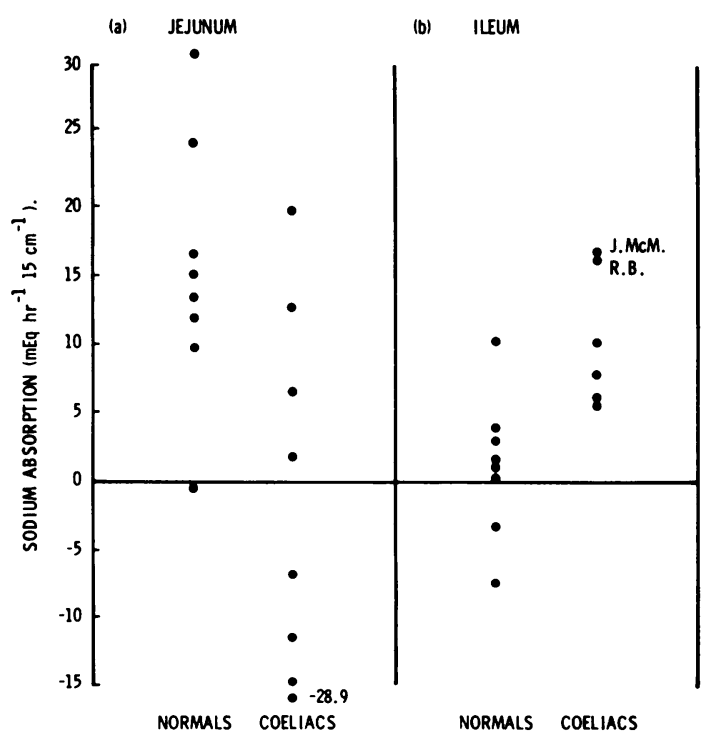

Fig 4 Sodium absorption from the jejunum (a) and from the ileum $(b)$. Negative sign indicates net secretion into the lumen of the small intestine. 


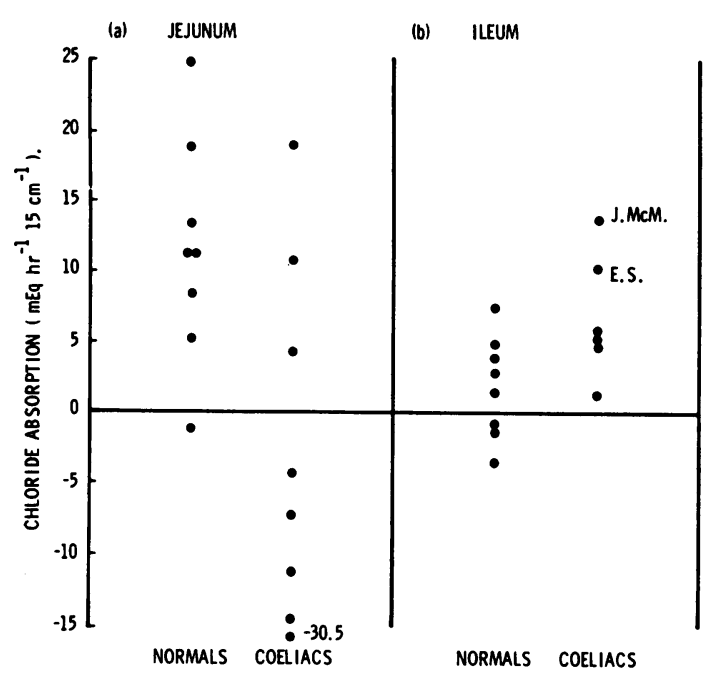

Fig 5 Chloride absorption from the jejunum (a) and from the ileum (b). Negative sign indicates net secretion into the lumen of the small intestine.

absorption by the group of patients with coeliac disease $(-4.3 \pm 31 \cdot 4)$ compared with the group of normal controls $(11.5 \pm 15.8 ; \mathrm{P}<0.05$; fig 5a). Values are the mean absorption rates expressed as m-equiv $\mathrm{hr}^{-1} 15 \mathrm{~cm}^{-1} \pm 2 \mathrm{SD}$. The same three patients who secreted bicarbonate and sodium also secreted chloride into the lumen of the jejunum (values below 2SD of the normal mean).

\section{ILEAL MOR PHOLOGY}

In contrast to the findings in the jejunum, the ileum was less severely involved (table II). Ileal biopsies from three patients however, M.H., P.F., and C.F., were grossly abnormal, having severe abnormalities of villous height, mucosal thickness, and surface cell height. None of the other five biopsies were normal according to the criteria of Stewart et al (1967). Four had reduced villous height (172-306 $\mu$ ) compared with the normal subjects. It was not possible to measure the mucosal thickness of F.A.'s ileal biopsy.

\section{ILEAL FUNCTION}

\section{Bicarbonate absorption}

The rates of bicarbonate absorption in the ileum are shown in figure $1 \mathrm{~b}$. The normal subjects absorbed bicarbonate very poorly in the ileum $(-0.4 \pm 2 \cdot 5$; values are the mean absorptive rates expressed as m-equiv hr-1 $15 \mathrm{~cm}^{-1} \pm 2 \mathrm{SD}$ ) compared with the jejunum (fig 1a). Four subjects exhibited net secretion of bicarbonate ions into the lumen of the ileum.
These findings indicate that in functional terms the test segment was positioned correctly in the ileum of each normal subject studied. Six out of the eight patients with coeliac disease handled bicarbonate ions in a similar way to the normal subjects (values within 2SD of normal mean) indicating that in these subjects the ileal test segment was correctly positioned. Significant absorption of bicarbonate was seen during 'ileal' perfusion of two coeliac patients $\left(2 \cdot 6,2 \cdot 7 \mathrm{~m}\right.$-equiv $\mathrm{hr}^{-1} \pm 15 \mathrm{~cm}^{-1}$; values greater than 2SD of the normal mean). The results of the ileal perfusions carried out in these two patients are therefore not included in the present study because one likely explanation for the high absorptive values is that the perfusion tube was wrongly positioned in a more proximal area of the small intestine. Recent experimental evidence suggests that this is a valid assumption because a further group of coeliac patients were found to have either normal or increased ileal luminal $\mathrm{pH}$ compared with normal subjects as measured using a radio telemetry capsule (Fairclough, Silk, Perry, Hicks, Clark, and Dawson, 1975; Meldrum, Watson, Riddle, Bown, and Sladen, 1972).

\section{Glucose absorption}

The rates of glucose absorption are shown in fig $2 b$. In contrast to glucose absorption in the jejunum (fig 2a) the group of coeliac patients absorbed glucose normally in the ileum (16.9 \pm 13.8) compared with the control group (12.5 \pm 10.6; values are the mean absorptive rates expressed as mmol hr-1 $15 \mathrm{~cm}^{-1} \pm 2 \mathrm{SD}$ ). Two patients (E.S. and R.B.) had absorption values above the normal range (one value greater than $2 \mathrm{SD}$ of the normal mean).

\section{Water absorption and electrolyte absorption}

The rates of water absorption in the ileum are shown in fig $3 \mathrm{~b}$ and the rates of sodium and chloride absorption are shown in figs $4 \mathrm{~b}$ and $5 \mathrm{~b}$ respectively. There was no significant difference between the rates of ileal water absorption during perfusion of the group of coeliac patients $(95 \cdot 3 \pm 82 \cdot 1)$ compared with the group of normal controls $(51 \cdot 2 \pm 72 \cdot 0 ; \mathrm{t}=2 \cdot 14, \mathrm{P}>0.05 ;$ fig $3 \mathrm{~b})$. Two patients (J.Mc.M. and R.B.) had absorption, values greater than 2SD of the normal mean. The group of coeliac patients absorbed sodium faster (10.2 \pm $10 \cdot 1)$ than the normal control group $(1 \cdot 1 \pm 10 \cdot 2$; $P<0.01$; fig $4 \mathrm{~b})$ : values are the mean absorptive rates expressed as m-equiv $\mathrm{hr}^{-1} 15 \mathrm{~cm}^{-1} \pm 2 \mathrm{SD}$. Two coeliac patients (J.Mc.M. and R.B.) had absorption values greater than 2SD of the normal mean. Similarly the group of coeliac patients absorbed chloride faster $(6.8 \pm 9.0)$ than the 
normal control group $(1.8 \pm 7 \cdot 2 ; \mathrm{P}<0.02$; fig $5 \mathrm{~b})$; values are the mean absorption rates expressed as m-equiv $\mathrm{hr}^{-1} 15 \mathrm{~cm}^{-1} \pm 2 \mathrm{SD}$. Two patients (J.Mc.M. and E.S.) had absorption values greater than 2SD of the normal mean.

\section{Discussion}

The results of the jejunal perfusion experiments showed that not only was absorption of glucose, water, and electrolytes severely impaired in the group of patients with coeliac disease, but that net secretion occurred into the gut lumen during perfusion of a number of individual patients. These findings are in general agreement with all the recent perfusion studies carried out to investigate jejunal function in coeliac disease (Schedl and Clifton, 1963; Holdsworth and Dawson, 1965; Fordtran et al, 1967; Schmid et al, 1969; Russell et al, 1972; Silk et al, 1974a; Kumar et al, 1974). We have previously reported (Kumar et al, 1974) that three out of nine patients with untreated coeliac disease absorbed glucose normally from the jejunum. We believe that the discrepancy between those results and the present findings is due to differences in experimental technique rather than differences in patient selection. Sladen (1970) showed that luminal glucose concentrations along a $45 \mathrm{~cm}$-segment fell in an exponential fashion during perfusion of a glucose saline solution. Thus it would be easier to highlight defects in absorption using a $15-\mathrm{cm}$ segment rather than a $30-\mathrm{cm}$ segment which was used in the study of Kumar et al (1974).

In contrast to the results of the jejunal perfusions, the ileal perfusion studies show that the coeliac patients have the same or greater capacity to absorb glucose, water, and electrolytes compared with normal subjects. Indeed every patient (including P.F. and M.H. whose results are excluded) had absorptive values for water, sodium, and chloride that were greater than normal mean values. Elias et al (1973) showed that two out of nine patients with coeliac disease absorbed vitamin $\mathbf{B}_{12}$ to a greater extent than normal controls. Schedl, Pierce, Rider, and Clifton (1968) showed that two patients with coeliac disease absorbed methionine faster from the ileum than four normal control subjects. These latter findings taken in conjunction with the results presented in this paper substantiate the original suggestion of Schedl and Clifton (1963) that the distal small intestine in coeliac disease has the ability to adapt to the damage and loss of absorptive capacity in the proximal small intestine.

The absorptive capacity of the terminal ileum of patients four months after ileostomy is greatly enhanced compared with that of the normal terminal ileum (Wright, Cleveland, Tilson, and Herskovic, 1969). Similarly, the absorptive capacity of the jejunum of patients after small bowel resection is enhanced compared with controls (Dowling and Booth, 1966; Weinstein, Shoemaker, Hersh, and Wright, 1969). Detailed histological studies indicate that the increased absorptive capacity is due to mucosal cell hyperplasia (Porus, 1965; Wright et al, 1969), an explanation which is adequately supported by experimental studies recently carried out in the rat (Gleeson et al, 1972). The present histological studies have not proved helpful in providing an explanation as to why ileal function is enhanced in some coeliac patients. It was not always possible to obtain peroral biopsies from the distal ileum, and apart from attaching the biopsy capsule to the test segment of the perfusion tube, there would appear to be no way of ensuring that ileal biopsy and perfusion are carried out at the same site. All but one (patient E.S.) of the ileal biopsies were undoubtedly taken proximal to the perfusion site, and all showed minor to severe (patients M.H. and P.F.) morphological abnormalities indicating a degree of proximal or midileal involvement in coeliac disease. It is of note, however, that the coeliac patients (J.Mc.M., E.S., and R.B.), who showed evidence of ileal adaptation (absorption values greater than 2SD of normal mean), had greater ileal surface cell heights than the other coeliac patients and there was a trend for these same three patients to have taller villi than the remaining coeliacs. It is most likely that the enhanced ileal function in coeliac disease is due to distal ileal mucosal cell hyperplasia occurring in response to the jejunal mucosal lesion. In support of this explanation, vitamin $\mathbf{B}_{12}$ absorption, normally limited by the availability of receptor sites (Donaldson, Robins, Small, and Mathan, 1971), is enhanced in some patients with coeliac disease (Elias et al, 1973). A much more detailed study of ileal morphology in coeliac disease is needed before firmer conclusions can be drawn.

There was no consistent correlation between ileal function and severity of symptoms. It is interesting though that none of the patients whohad evidence of enhanced ileal function presented with severe diarrhoea (table I). Phillips and Giller (1973) recently showed that a patient with coeliac disease had enhanced colonic function with respect to water and electrolyte absorption. The present study indicates that patients with coeliac disease may have enhanced ileal function. Two previous studies have shown that occasionally jejunal function may be normal in coeliac disease (Silk et al, 1974a; Kumar et al, 1974). There are thus three reasons why patients with untreated 
adult coeliac disease do not always present with severe diarrhoea.

We are indebted to the North East Thames Regional Health Authority and the Board of Governors of St Bartholomew's Hospital for financial support. We are grateful to the Pathology Department for carrying out the glucose and bicarbonate estimations and we would like to thank Professor Sir Eric Scowen for the use of his laboratory facilities.

\section{References}

Booth, C. C., Evans, K. T., Menzies, T., and Street, D. F. (1959) Intestinal hypertrophy following partial resection of the small bowel in the rat. Brit. J. Surg., 46, 403-410.

Brown, M. E. (1961). Ultra-micro sugar determinations using 2,9 dimethyl-1, 10-phenanthroline hydrochloride (Neocuproine). Diabetes, 10, 60-62.

Bury, K. D. (1972). Carbohydrate digestion and absorption after massive resection of the small intestine. Sur. Gynec. Obstet., 135, 177-187.

Crosby, W. H., and Kugler, H. W. (1957). Intraluminal biopsy of the small intestine: the intestinal biopsy capsule. Amer. J. dig. Dis., 2, 236-241.

Donaldson, R. M., Robins, S. R., Small, D. M., and Mathan, V. I. (1971). Quantitation of absorptive capacity for vitamin $\mathbf{B}_{12}$ ileal absorptive surface area, and total number of intrinsic factor-bound vitamin $B_{12}$ (IF-B $\left.B_{12}\right)$ receptor sites in the hamster. (Abstr.) J. clin. Invest., 50, 26a.

Dowling, R. H., and Booth, C. C. (1966). Functional compensation after small-bowel resection in man: demonstration by direct measurement. Lancet, 2, 146-147.

Dowling, R. H., and Booth, C. C. (1967). Structural and functional changes following small intestinal resection in the rat. Clin. Sci., 32, 139-149.

Elias, E., MacKinnon, A. M., Short, M. D., and Dowling, R. H. (1973). Factors controlling ileal adaptation after proximal small bowel resection and in coeliac disease (Abstr.). Europ. J. clin. Invest., 3, 226.

Fairclough, P. D., Silk, D. B. A., Perry, P. M., Hicks, B., Clark, M. L., and Dawson, A. M. (1975). Changes in ileal pH in coeliac disease. (In preparation).

Fordtran, J. S., Rector, F. C., Locklear, T. W., and Ewton, M. F. (1967). Water and solute movement in the small intestine of patients with sprue. J. clin. Invest., 46, 287-298.

Gleeson, M. H., Dowling, R. H., and Peters, T. J. (1972). Biochemical changes in intestinal mucosa after experimental small bowel by-pass in the rat. Clin. Sci., 43, 743-757.

Holdsworth, C. D., and Dawson, A. M. (1964). Absorption of monosaccharides in man. Clin. Sci., 27, 371-379.

Holdsworth, C. D., and Dawson, A. M. (1965). Glucose and fructose absorption in idiopathic steatorrhoea. Gut, 6, 387-391

Kumar, P. J., Silk, D. B. A., Rousseau, B., Pagaltsos, A. S., Clark, M. L., Dawson, A. M., and Marks, R., (1974). Assessment of jejunal function in patients with dermatitis herpetiformis and adult coeliac disease using a perfusion technique. Scand. J. Gastroent., 9, 793-798.

Langley, R. (1968). Practical Statistics for Non-Mathematical People. Pan Books, London.

Loran, M. R., and Althausen, T. L. (1958). Hypertrophy and changes in cholinesterase activities of the intestine, erythrocytes, and plasma after 'partial' resection of the small intestine of the rat. Amer. J. Physiol., 193, 516-520.

MacKinnon, A. M. (1972). Intestinal adaptation of vitamin $\mathbf{B}_{12}$ absorption. (Abstr.). Clin. Sci., 42, 29p.

Meldrum, S. J., Watson, B. W., Riddle, H. C., Bown, R. L., and Sladen, G. E. (1972). pH profile of gut as measured by radiotelemetry capsule. Brit. med. J., 2, 104-106.

Perry, P. M. (1973). Bile salt absorption following small bowel resection. MS Thesis, London University.

Phillips, S. F., and Giller, J. (1973). The contribution of the colon to electrolyte and water conservation in man. J. Lab. clin. Med., 81, 733-746.

Phillips, S. F., and Summerskill, W. H. J. (1967). Water and electrolyte transport during maintenance of isotonicity in human jejunum and ileum. J. Lab. clin. Med., 70, 686-698.

Porus, R. L. (1965). Epithelial hyperplasia following massive small bowel resection in man. Gastroenterology, 48, 753-757.

Russell, R. I., Allan, J. G., Gerskowitch, V. P., and Robertson, J. W. K. (1972). A study by perfusion techniques of the absorption abnormalities in the jejunum in adult coeliac disease. Clin. Sci., 42, 735-741.

Schedl, H. P., and Clifton, J. A. (1963). Solute and water absorption by the human small intestine. Nature (Lond.), 199, 1264-1267.

Schedl, H. P., Pierce, C. E., Rider, A., and Clifton, J. A. (1968). Absorption of L-methionine from the human small intestine. $J$. clin. Invest., 47, 417-425.

Schmid, W. C., Phillips, S. F., and Summerskill, W. H. J. (1969). Jejunal secretion of electrolytes and water in non-tropical sprue. J. Lab. clin. Med., 73, 772-783.

Silk, D. B. A. (1974). The absorption of peptides in man. MD Thesis, London University.

Silk, D. B. A., Kumar, P. J., Perrett, D., Clark, M. L., and Dawson, A. M. (1974a). Amino acid and peptide absorption in patients with coeliac disease and dermatitis herpetiformis. Gut, 15, 1-8.

Silk, D. B. A., Webb, J. P. W., Lane, A. E., Clark, M. L., and Dawson, A. M. (1974b). Functional differentiation of human jejunum and ileum: a comparison of the handling of glucose, peptides and amino acids. Gut, 15, 444-449.

Silk, D. B. A., Perrett, D., Webb, J. P. W., and Clark, M. L. (1974c). Absorption of two tripeptides by the human small intestine: a study using a perfusion technique. Clin. Sci., 46, 393-402.

Skeggs, L. T., Jr., and Hochstrasser, H. (1964). Multiple automatic sequential analysis. Clin. Chem., 10, 918-936.

Sladen, G. E. (1970). A study of the intestinal absorption of fluid and electrolytes in man. DM Thesis, University of Oxford.

Stewart, J. S., Pollock, D. J., Hoffbrand, A. V., Mollin, D. L.. and Booth, C. C. (1967). A study of proximal and distal intestinal structure and absorptive function in idiopathic steatorrhoea. Quart. J. Med., 36, 425-444.

Tilson, M. D., and Wright, H. K. (1970). Adaptation of functioning and bypassed segments of ileum during compensatory hypertrophy of the gut. Surgery, 67, 687-693.

Weinstein, L. D., Shoemaker, C. P., Hersh, T., and Wright, H. K. (1969). Enhanced intestinal absorption after small bowel resection in man. Arch. Surg., 99, 560-562.

Weser, E., and Hernandez, M. H. (1971). Studies of small bowel adaptation after intestinal resection in the rat. Gastroenterology, 60, 69-75.

Wingate, D. L., Sandberg, R. J., and Phillips, S. F. (1972). A comparison of stable and 1'C-labelled polythylene glycol as volume indicators in the human jejunum. Gut, 13, 812-815.

Wright, H. K., Cleveland, J. C., Tilson, M. D., and Herskovic, T. (1969). Morphology and absorptive capacity of the ileum after ileostomy in man. Amer. J. Surg., 117, 242-245. 